\title{
Pemberdayaan Perpustakaan Kelurahan dalam Menunjang Kegiatan Belajar Mengajar di Paud Restu Bunda Kelurahan Dusun Curup
}

\author{
Rhoni Rodin' Khusnul Khotimah' ${ }^{2}$ Lia Aprien ${ }^{3}$ \\ 1,2,3 Perpustakaan Institut Agama Islam Negeri (IAIN) Curup \\ email: rhoni.rodin@iaincurup.ac.id \\ khusnulkhotimah29090@gmail.com \\ Liaaprien22@gmail.com
}

\begin{abstract}
The purpose of this research is to find out and analyze how the empowerment of village libraries to support teaching and learning activities in PAUD Restu Bunda, Dusun Curup. The study used a descriptive approach with qualitative analysis. The type of data in this study is qualitative. The results showed that the empowerment of the village library departed from the understanding that the library is a center of learning resources as well as a forum for various disciplines of science that also support or as a means of educating the life of the nation especially in education and teaching. Therefore, based on the history of the library, it can be understood that the empowerment of this library is motivated by the existence of the Gernas Baku movement and the program of every village has one PAUD. Responding to these two programs, Kelurahan Dususn Curup has the initiative to utilize library collections for teaching and learning activities at PAUD Restu Bunda. Dusun Curup's Library Service has several advantages in supporting teaching and learning activities for PAUD students, namely: First, it is free; second, be open; and third, foster a spirit of reading from an early age.
\end{abstract}

\begin{abstract}
Abstrak
Tujuan dari penelitian ini adalah untuk mengetahui dan menganalisis bagaimana pemberdayaan perpustakaan kelurahan dalam menunjang kegiatan belajar mengajar di PAUD Restu Bunda Kelurahan Dusun Curup. Penelitian menggunakan pendekatan deskriptif dengan analisis kualitatif. Jenis data dalam penelitian ini adalah bersifat kualitatif. Hasil penelitian menunjukkan bahwa Pemberdayaan perpustakaan kelurahan berangkat dari pemahaman bahwa perpustakaan merupakan pusat sumber belajar yang sekaligus sebagai wadah dari berbagai disipilin ilmu pengetahuan yang juga menunjang atau sebagai sarana dalam mencerdaskan kehidupan bangsa khususnya di bidang pendidikan dan pengajaran. Oleh karena itu, berdasarkan sejarah dari perpustakaan tersebut, dapat dipahami pemberdayaan perpustakaan ini dilatarbekangi karena adanya gerakan Gernas Baku dan program setiap satu desa satu PAUD. Menyikapi kedua program inilah maka pihak kelurahan mempunyai inisiatif untuk memanfaatkan koleksi perpustakaan bagi kegiatan beajar mengajar di PAU Restu Bunda. Layanan Perpustakaan Kelurahan Dusun Curup memiliki beberapa keunggulan dalam menunjang kegiatan belajar mengajar bagi siswa PAUD, yaitu: Pertama, bersifat gratis; kedua, bersifat terbuka; dan ketiga, menumbuhkan semangat membaca sejak dini.
\end{abstract}

Keyword:

Village library, teaching

and learning activities,

PAUD Restu Bunda

\section{Kata kunci :}

Perpustakaan Kelurahan, Kegiatan Belajar Mengajar, PAUD Restu Bunda

\section{A. PENDAhULUAN}

Perpustakaan kelurahan merupakan jenis perpustakaan umum yang berada di lingkungan kelurahan. Perpustakaan ini merupakan ujung tombak layanan perpustakaan yang sangat dekat dengan kehidupan masyarakat. Secara legalitas formal, perpustakaan kelurahan mempunyai dasar hukum pelaksanaanya, yaitu Surat Keputusan Menteri Dalam Negeri dan Otonomi Daerah Nomor 3 Tahun 2001, tentang Perpustakaan Desa/Kelurahan (Menteri Dalam Negeri dan Otonomi Daerah, 2001). Secara definitif perpustakaan kelurahan 
adalah "perpustakaan masyarakat" sebagai salah satu sarana/media untuk meningkatkan dan mendukung kegiatan pendidikan masyarakat kelurahan, yang merupakan bagian integral dari kegiatan pembangunan kelurahan.

Berdasarkan pengertian tersebut terdapat empat kata kunci tentang perpustakaan kelurahan yaitu: (1) perpustakaan berbasis masyarakat, (2) berfungsi sebagai sarana dan media belajar, (3) untuk meningkatkan dan mendukung pendidikan masyarakat, dan (4) merupakan bagian integral pembangunan. Jika dilihat dari empat kata kunci tersebut pengertian hakiki dari perpustakaan kelurahan adalah perpustakaan yang dikembangkan dan didirikan atas inisitif dan prakarsa dari pemerintah kelurahan, penyelenggaraannya juga menjadi tanggung jawab pemerintah di tingkat kelurahan, yang digunakan masyarakat sebagai media untuk mendukung pendidikan informal di lingkungan masyarakat yang menjadi bagian yang tak terpisahkan dari program pembangunan dalam pelaksanaan pembangunan kelurahan (Darmono, 2015).

Pada dasarnya perpustakaan kelurahan merupakan salah satu bagian dari layanan pendidikan kepada masyarakat. Selain menyediakan buku dan koleksi yang baik, perpustakaan kelurahan menciptakaan kegiatan untuk menunjang pendidikan. Oleh karena itu, perpustakaan kelurahan perlu melakukan kerjasama dengan berbagai sekolah (misalnya dengan Pendidikan Anak Usia Dini) yang ada di sekitarnya. Hal ini bertujuan untuk membangun kemitraan antara perpustakaan kelurahan dengan lingkungannya. Dengan cara ini maka fungsi pendidikan dari perpustakaan kelurahan dapat diwujudkan.

Perpustakaan kelurahan merupakan wadah penyedia bahan bacaan yang berfungsi salah satu sumber belajar bagi masyarakat dalam rangka mencerdaskan dan memberdayakan masyarakat, serta menunjang pelaksanaan pendidikan nasional sebagaimana tertuang dalam Surat Keputusan Menteri dalam Negeri dan Otonomi Daerah Nomor 3 Tahun 2001. Sedangkan menurut Sutarno (2008), Perpustakaan desa/ kelurahan adalah lembaga layanan publik yang berada di desa/ kelurahan. Sebuah unit layanan yang dikembangkan dari, oleh dan untuk masyarakat tersebut, tujuannya adalah untuk memberikan layanan dan memenuhi kebutuhan warga yang berkaitan dengan informasi, ilmu pengetahuan, pendidikan dan rekreasi kepada semua lapisan masyarakat. Masyarakat yang dilayani meliputi semua penduduk yang beraneka ragam latar belakangnya. Mereka tinggal di suatu kelurahan dengan memiliki suatu ikatan yang erat dan bervariasi. Dengan demikian dapat dipahami bahwa perpustakaan kelurahan merupakan lembaga pelayanan kepada masyarakat yang menyediakan berbagai informasi untuk memenuhi kebutuhan hidupnya, dalam rangka menunjang program pembelajaran sepanjang hayat dan mencerdaskan kehidupan masyarakat di tingkat kelurahan.

Perpustakaan yang telah dibangun di suatu kelurahan hendaknya berdaya guna dan bermanfaat bagi masyarakat. Artinya suatu perpustakaan keberadaannya hendaknya dimanfaatkan secara maksimal oleh masyarakat. Salah satu upaya yang bisa dilakukan misalnya memberdayakan perpustakaan untuk mendukung kegiatan belajar mengajar bagi pendidikan anak usia dini (PAUD) yang ada di kelurahan tersebut. Peran perpustakaan merupakan kedudukan, posisi, dan bagaimana perpustakaan memberikan pengaruh ke masyarakat di lingkungan perpustakaan. Perpustakaan sebagai pusat informasi memiliki peran strategis di tengah masyarakat. Pada cakupan yang lebih luas perpustakaan dapat berperan sebagai agen perubahan, pembangunan, serta agen budaya dan pengembangan ilmu pengetahuan dan teknologi (Suwarno, 
2011).

Kementerian Pendidikan Nasional (Kemdiknas) melalui Undang-Undang (UU) Nomor 20 Tahun 2003 tentang Sistem Pendidikan Nasional telah mengamanatkan dilaksanakannya pendidikan kepada seluruh rakyat indonesia sejak anak dilahirkan. Pendidikan anak pada usia dini disadari betul memegang peranan sangat penting. Oleh karena itu, untuk mendukung proses belajar-mengajar di kelas, perpustakaan memegang peranan yang sangat penting dalam menunjang kegiatan belajar mengajar. Terlebih lagi biasanya anak-anak tingkat usia dini lebih menyenangi buku-buku cerita yang bergambar. Menyikapi hal ini hendaknya koleksi perpustakaan memperbanyak koleksinya yang bergambar baik secara kualitas maupun kuantitas. Oleh karena itu, kegiatan pengembangan koleksi harus betul-betul memperhatikan sasaran pemustakanya.

Usia dini adalah masa dimana anak mengalami masa keemasan atau golden ages. Banyak penelitian menunjukkan betapa masa dini usia, yaitu masa lima tahun ke bawah, merupakan golden ages (masa keemasan) bagi perkembangan kecerdasan anak. Salah satu hasil penelitian menyebutkan bahwa pada usia 4 tahun kapasitas kecerdasan anak telah mencapai 50\%. Seperti diungkapkan Direktur Pendidikan Anak Dini Usia (PADU), Depdiknas, Dr. Gutama, kapasitas kecerdasan itu mencapai $80 \%$ di usia 8 tahun. Ini menunjukkan pentingnya memberikan perangsangan pada anak dini usia, sebelum masuk sekolah.

Anak usia dini adalah sosok individu yang sedang menjalani suatu proses perkembangan dengan pesat dan fundamental bagi kehidupan selanjutnya. Anak usia dini berada pada rentang usia 0-6 tahun. Pada masa ini proses pertumbuhan dan perkembangan dalam berbagai aspek sedang menjalani masa yang cepat dalam rentang perkembangan hidup manusia. Usia dini lahir sampai enam tahun merupakan usia yang sangat menentukan dalam pembentukan karakter dan kepribadian seorang anak. Usia itu sebagai usia penting bagi pengembangan inteligensi permanen dirinya, mereka juga mampu meyerap informasi yang sangat tinggi.

Berangkat dari pemaparan di atas, maka perpustakaan Kelurahan Dusun Curup menyediakan koleksi-koleksi buku cerita bergambar sangat cocok untuk diterapkan pada siswa PAUD maupun sekolah dasar, dimana sampai saat ini koleksi yang ada berjumlah 281 judul (595 eksamplar). Dalam upaya meningkatkan kemampuan membaca permulaan, karena pelajaran membaca permulaan di kelas merupakan awal siswa mengenal simbol-simbol dan mengalihkodekannya menjadi bermakna. Ketika anak tidak dapat melakukannya, maka proses pembelajaran akan terhambat. Membaca merupakan syarat utama dalam pembelajaran yang harus dipenuhi. Menurut teori Piaget, anak usia sekolah dasar berada pada tahap operasional konkret. Hal ini menunjukkan bahwa anak sangat menyukai benda-benda yang nyata. Di samping itu, anak juga memiliki daya fantasi yang sangat tinggi. Berdasarkan asumsi tersebut, agar lebih menarik dan menumbuhkan motivasi anak terhadap sesuatu hal, diperlukan media yang dapat menyalurkan imajinasi yang kreatif pada anak, dimana media tersebut salah satunya berupa buku bergambar.

Berdasarkan penjelasan di atas, maka penulis tertarik untuk meneliti dan menganalisis lebih lanjut bagaimana pemberdayaan perpustakaan kelurahan dalam menunjang kegiatan belajar mengajar di PAUD Restu Bunda Kelurahan Dusun Curup. Tujuan dari penulisan ini adalah untuk menganalisis bagaimana pemberdayaan dan pemanfaatan perpustakaan kelurahan dalam menunjang kegiatan belajar mengajar di PAUD Restu Bunda Kelurahan Dusun Curup. 


\section{B. KAJIAN TEORITIS}

\section{Perpustakaan Kelurahan}

Pada dasarnya lahirnya Undang-Undang Nomor 43 Tahun 2007 tentang Perpustakaan merupakan tatanan legalitas perpustakaan desa/ kelurahan, dimana di dalamnya sudah diatur keberadaannya dan merupakan bagian dari perpustakaan umum yang berada di wilayah desa/ kelurahan pada suatu kecamatan kabupaten/ kota suatu daerah. Selain itu, jauh sebelumnya telah diatur dalam Undang-Undang Dasar Negara Republik Indonesia 1945 Pasal $28 \mathrm{f}$ yang berbunyi "Setiap orang berhak untuk berkomunikasi dan memperoleh informasi untuk mengembangkan pribadi dan lingkungan sosialnya, serta berhak untuk mencari, memperoleh, memiliki, menyimpan, mengolah dan menyampaikan informasi dengan segala jenis saluran yang tersedia". Dalam hal ini desa/kelurahan sebagai bagian terkecil tempat berkumpulnya masyarakat suatu wilayah mempunyai hak yang sudah diatur dalam UndangUndang Dasar 1945 tersebut.

Peraturan Menteri Dalam Negeri Nomor 30 Tahun 2006 tentang Tata Cara Urusan Pemeritahan Kabupaten/Kota kepada Desa, yang termaktub dalam pasal 2 ayat 1 , Jenis Urusan Pemerintah Kabupaten/Kota yang dapat diserahkan pengaturannya kepada Desa/ kelurahan salah satunya yaitu Bidang Arsip dan Perpustakaan. Urusan yang diatur antara lain masalah: Pengadaan dan pengelolaan Taman Bacaan dan Perpustakaan Desa/ kelurahan, serta Pengelolaan perpustakaan buku-buku petunjuk teknis. Hal ini diperkuat juga oleh Keputusan Menteri Dalam Negeri dan Otonomi Daerah Nomor 3 Tahun 2001 tentang Perpustakaan Desa / Kelurahan, dan dijelaskan pada pasal 7 bahwa :

a. Kepala Desa/Kepala Kelurahan atau tokoh masyarakat yang ditetapkan oleh Kepala Desa/Kepala Kelurahan merupakan Pembina
Perpustakaan Desa/Kelurahan.

b. Pemerintah dan Pemerintah Daerah dapat memfasilitasi Pemerintah Desa/Kelurahan dalam membina Perpustakaan Desa/ Kelurahan.

c. Pemerintah Daerah dapat membina penyelenggaraan Perpustakaan Desa/Kelurahan sesuai dengan ruang lingkup kewenangan.

Regulasi-regulasi di atas tentunya memberi penguatan atau payung hukum bagi pemerintah desa/ kelurahan untuk menyelenggarakan perpustakaan secara maksimal sehingga keberadaan perpustakaan bisa memberi manfaat yang besar bagi kecerdasan kehidupan masyarakat di suatu desa/ kelurahan. Sebagaimana Pemerintah melalui surat keputusan Menteri dalam Negeri dan Otonomi Daerah Nomor 3 Tahun 2001 tentang pembentukan perpustakaan desa/ kelurahan, telah dijelaskan mengenai pentingnya perpustakaan desa/ kelurahan untuk mencerdaskan dan memberdayakan masyarakat serta menunjang pelaksanaan pendidikan nasional perlu dikembangkan sebagai salah satu sumber belajar bagi masyarakat dalam bentuk perpustakaan desa/ kelurahan.

Perpustakaan desa/ kelurahan adalah wadah penyedia bahan bacaan sebagai salah satu sumber belajar bagi masyarakat dalam rangka mencerdaskan dan memberdayakan masyarakat, serta menunjang pelaksanaan pendidikan nasional (Surat Keputusan Menteri dalam Negeri dan Otonomi Daerah Nomor 3 Tahun 2001). Sebuah unit layanan yang dikembangkan dari, oleh dan untuk masyarakat tersebut. Tujuannya untuk memberikan layanan dan memenuhi kebutuhan warga yang berkaitan dengan informasi, ilmu pengetahuan, pendidikan dan rekreasi kepada semua lapisan masyarakat. Masyarakat yang dilayani terdiri atas semua penduduk yang beraneka ragam latar belakangnya. Mereka tinggal di suatu desa/ kelurahan dengan memiliki suatu ikatan yang erat 
Pemberdayaan Perpustakaan Kelurahan dalam Menunjang Kegiatan Belajar Mengajar di Paud Restu Bunda Kelurahan Dusun Curup

Rhoni Rodin, Khusnul Khotimah, Lia Aprien

dan bervariasi. Berdasarkan uraian menurut dua ahli tersebut dapat dilihat, bahwa perpustakaan desa/ kelurahan merupakan lembaga pelayanan kepada masyarakat yang menyediakan berbagai informasi untuk memenuhi kebutuhan hidupnya, dalam rangka menunjang program pembelajaran sepanjang hayat dan sebagai bentuk pemberdayaan masyarakat.

Perpustakaan itu mempunyai peran yang strategis bagi masyarakat desa/ kelurahan untuk meningkatkan pengetahuan dan pengalaman. Terbentuknya perpustakaan desa/ kelurahan adalah untuk sarana pelayanan kepada masyarakat sebagai penyedia sumber informasi yang cepat, tepat dan murah untuk menunjang program wajib belajar dan program pendidikan keterampilan masyarakat lainnya, serta membantu warga untuk mengembangkan kemampuan yang dimilikinya sehingga dapat bermanfaat bagi masyarakat di sekitarnya, sejauh kemampuan tersebut dapat dikembangkan dengan bantuan bahan pustaka. Fungsi ini disebut fungsi pendidikan berkesinambungan.

Dengan demikian pemanfaatan perpustakaan desa/kelurahan adalah penggunaan koleksi perpustakaan untuk mencerdaskan, memberdayakan masyarakat serta menunjang pelaksanaan pendidikan nasional. Pemanfaatan ini dapat dilaksanakan dengan mengelola sumber daya perpustakaan (Ns, 2006). Sumber daya perpustakaan adalah semua unsur dan faktor yang ada di perpustakaan yang dipergunakan untuk menyelenggarakan perpustakaan. Oleh karena itu penyelenggaraan kegiatan perpustakaan merupakan pengelolaan sumber daya perpustakaan.

Sebagaimana perpustakaan pada umumnya, perpustakaan desa mempunyai fungsi khusus. Fungsi ini tentunya agak berbeda dengan perpustakaan yang lain. Fungsi Perpustakaan Desa/ Kelurahan menurut Pedoman Penyelenggara Perpustakaan Desa, adalah sebagai lembaga layanan bahan pustaka dan informasi kepada masyarakat untuk kepentingan pendidikan, informasi, penerangan, dan rekreasi.

Menurut Darmono (2015) salah satu fungsi perpustakaan kelurahan adalah fungsi pendidikan. Perpustakaan menyediakan berbagai informasi yang meliputi bahan tercetak, terekam maupun koleksi lainnya sebagai sarana untuk menerapkan tujuan pendidikan. Melalui fungsi ini manfaat yang diperoleh pemakai adalah: a) agar pemakai mendapat kesempatan untuk mendidik diri sendiri secara berkesinambungan, b) untuk membangkitkan dan mengembangkan minat akademik pemakai yaitu mempertinggi kreativitas dan kegiatan intelektual, c) mendorong kecepatan untuk memecahkan berbagai masalah yang berkaitan dengan masalah kehidupan serta masalah-masalah lainnya yang dihadapi pemakai d) mempertinggi sikap sosial dan menciptakan masyarakat yang demokratis, e) mempercepat penguasaan dalam bidang pengetahuan dan teknologi baru.

Perpustakaan kelurahan merupakan salah satu bagian dari layanan pendidikan ke masyarakat. Selain menyediakan buku dan koleksi yang baik, perpustakaan desa menciptakaan kegiatan untuk menunjang pendidikan. Sudah ada perpustakaan kelurahan sebagai sentra pengembangan usaha kegiatan rakyat (UKM) dalam skala kecil (skala rumah tangga). Perpustakaan kelurahan sebagai tempat pendidikan dan latihan singkat pembuatan berbagai produk industri rumah tangga. Selain itu perpustakaan perlu juga melakukan kerjasama dengan berbagai sekolah (misalnya dengan Sekolah Dasar) yang ada di sekitarnya. Ini bertujuan untuk membangun kemitraan antara perpustakaan kelurahan dengan lingkungannya. Dengan cara ini maka fungsi pendidikan dari perpustakaan kelurahan dapat diwujudkan.

Pada dasarnya kegiatan perpustakaan sangat 
bervariasi, tergantung jenis perpustakaan dan tujuan dari perpustakaan itu sendiri. Namun secara umum ada lima kegiatan perpustakaan, yaitu (Sutarno, 2006):

\section{Pengadaan Koleksi}

Pengadaan koleksi merupakan proses awal dalam mengisi perpustakaan dengan sumbersumber informasi. Adapun hal pokok yang harus ditetapkan berkaitan dengan koleksi seperti penyusunan rencana operasioanl pengadaan koleksi, menghimpun alat seleksi koleksi, survai bahan pustaka, dan menyeleksi bahan pustaka.

2. Pengolahan

Pengolahan adalah pekerjaan yang diawali sejak koleksi diterima di perpustakaan sampai dengan penempatan di rak yang telah disediakan. Dalam pengolahan terdapat kegiatan berupa inventarisasi, klasifikasi, katalogisasi, pengecapan, pembuatan perlengkapan perpustakaan, penjajaran kartu dan penyusunan koleksi di rak.

3. Layanan

Layanan adalah kegiatan memberi bantuan kepada pengguna dalam memenuhi kebutuhan hidup sesuai yang diharapkannya. Di sebuah perpustakaan tentunya berbeda dengan layanan pada kegiatan kemasyarakatan yang lain seperti layanan kesehatan dan layanan keagamaan.

Perbedaan itu tentu terkait dengan tugas dan fungsi dari masing-masing bidang, tetapi pada dasarnya suatu layanan mempunyai prinsip-prinsip yang sama atau berdekatan, yaitu:

a. Sesuai dengan kebutuhan masyarakat yang dilayani.

b. Dilaksanakan secara cepat, tepat, dan akurat.

c. Menciptakan kesan yang menarik, sehingga menimbulkan kepuasan masyarakat.
Secara khusus Murniaty (2013:11) menjelaskan jenis layanan yang biasanya ada di perpustakaan desa/ kelurahan seperti layanan sirkulasi, layanan referensi, layanan koleksi deposit, layanan multimedia, dan layanan perpustakaan keliling.

1. Administrasi Perpustakaan

Adapun kegiatan yang dimaksud administrasi perpustakaan disini adalah kegiatan yang berada di sekretariat, kegiatan ini merupakan penunjang kegiatan pokok. Kegiatan ini antara lain mengenai ketatausahaan, kepegawaian keuangan, dan kerumah tanggaan.

2. Sosialisasi

Istilah sosialisasi atau pemasyarakatan bagi perpustakaan selalu dikaitkan dengan upaya promosi perpustakaan, menjaring minat dan respon masyarakat dengan memberikan sesuatu yang berguna, mengembangkan kerjasama dengan berbagai pihak yang terkait, serta mengembangkan upaya mendekatkan dan membangun jembatan antara perpustakaan dan masyarakat pengguna.

Lebih lanjut sosialisasi perpustakaan dilakukan dalam rangka membangun citra positif perpustakaan. Dengan memaksimalkan lima hal tersebut di perpustakaan, maka sebuah perpustakaan dapat memenuhi kebutuhan dan selera pengunjung serta dapat memberikan sesuatu yang bermanfaat dan nilai tambah kepada masyarakat.

Nilai yang terkandung dalam Public Library Manifesto, yaitu perpustakaan sebagai gerbang menuju pengetahuan untuk menyediakan kondisi awal bagi perorangan atau kelompok dalam melakukan kegiatan belajar seumur hidup, pengambilan keputusan mandiri serta pembangunan budaya (Gill, 2001). Nilai ini selalu ada sebagai acuan yang melandasi berdirinya sebuah perpustakaan. Perpustakaan merupakan pusat lokal informasi, membuat semua jenis pengetahuan 
Pemberdayaan Perpustakaan Kelurahan dalam Menunjang Kegiatan Belajar Mengajar di Paud Restu Bunda Kelurahan Dusun Curup

Rhoni Rodin, Khusnul Khotimah, Lia Aprien

dan informasi dapat tersedia untuk para pengguna. Kegiatan perpustakaan yang bersifat aktif menjadikan masyarakat mudah memperoleh dan mencari informasi, keaktifan ini mendorong perpustakaan dalam memberikan layanan dan fasilitas yang baik atas dasar kesetaraan akses untuk semua pengguna tanpa memandang usia, ras, jenis kelamin, agama, dan bahasa.

Layanan dan fasilitas yang ada di perpustakaan harus terorganisir dengan baik dan dilakukan secara professional, sehingga dapat mendorong masyarakat dalam meningkatkan kemampuan mencari dan memperoleh informasi (Gill, 2001). Kemampuan tersebut diharapkan dapat menambah modal pengetahuan yang berguna bagi masyarakat, modal tersebuat nantinya dapat dimanfaatkan untuk meningkatkan kesejahteraan dalam bidang ekonomi, budaya, dan pendidikan. Masyarakat yang memiliki akses informasi lebih mudah untuk beradaptasi serta memanfaatkan lingkungan yang ada, informasi sebagai modal bisa ditindak lanjuti dengan sebuah tindakan. Melalui tindakan inilah masyarakat nantinya dapat memperoleh keuntungan langsung baik berupa materi maupun immateri, dengan begitu secara berlahan masyarakat telah melalukan proses pemberdayaan melalui kegiatan perpustakaan.

\section{Perpustakaan dan Kegiatan Belajar Mengajar Anak Usia Dini}

Menurut Undang-Undang Nomor 20 Tahun 2003 Tentang Sistem Pendidikan Nasional, pendidikan anak usia dini (PAUD) adalah suatu upaya pembinaan yang ditujukan kepada anak sejak lahir sampai dengan usia enam tahun yang dilakukan melalui pemberian rangsangan pendidikan untuk membantu pertumbuhan dan perkembangan jasmani dan rohani agar anak memiliki kesiapan dalam memasuki pendidikan lebih lanjut.

Pendidikan anak usia dini merupakan kunci utama sukses tidaknya sebuah program pendidikan nasional suatu bangsa. Penelitian di bidang neurologi menyebutkan selama tahun-tahun pertama, otak bayi berkembang pesat dengan menghasilkan neuron yang banyaknya melebihi kebutuhan. Hal itu harus diperkuat melalui berbagai rangsangan karena perkembangan otak bayi yang tidak diperkuat dengan rangsangan akan mengalami atrohy (menyusut dan musnah), karena hal inilah yang mempengaruhi kecerdasan anak. Dosis rangsangan yang tepat dan seimbang akan mampu melipatgandakan kemampuan otak 5-10 kali kemampuan sebelumnya. Ironisnya, pemerintah kita terhitung terlambat dalam memberikan perhatian kepada anak usia dini. Mereka dibiarkan tumbuh dan berkembang dalam kondisi "ala kadarnya". Sampai saat ini diperkirakan 80 persen anak usia dini belum tersentuh PAUD. Tatkala anak usia dini di Singapura sudah terjangkau semuanya dengan PAUD, anak usia dini di Indonesia masih dibayang-bayangi oleh ancaman gizi buruk.

Dunia anak adalah dunia bermain, dan Pendidikan Anak Usia Dini (PAUD) harus bertitik tolak dari kaidah ini. Pembelajaran anak usia dini harus dibedakan dengan pembelajaran anak usia sekolah dasar. Nuansa bermain tak boleh hilang dari model pembelajaran anak usia dini. Pembebanan yang berlebihan justru akan berakibat kontaproduktif bagi perkembangan sang anak. Anak bisa menjadi trauma dengan membaca, menulis, dan berhitung. Jadi, pembelajaran pada anak usia dini mestinya lebih bersifat memberi rangsangan pada anak agar tumbuh minatnya dalam membaca, menulis, dan berhitung. Perpustakaan dapat dijadikan salah satu alternatif untuk meningkatkan akses anak usia dini terhadap PAUD. Perpustakaan kelurahan tentunya dapat membuka layanan khusus yang ramah terhadap anak-anak dan menyediakan bahan bacaan yang sesuai untuk anak-anak usia dini. Layanan ini diberi ruang tersendiri sehingga 
layanan ini sangat relevan jika dikaitkan dengan visi dan misi perpustakaan yaitu meningkatkan minat baca masyarakat. Membuka layanan ramah anak-anak berarti merupakan upaya untuk menumbuhkan minat baca sejak usia dini.

\section{METODE PENELITIAN}

Penelitian ini menggunakan metode kualitatif.. Sedangkan jenis penelitian ini adalah penelitian eksploratif. Data dikumpulkan dengan teknik wawancara dan dokumentasi. Selanjutnya analisis data dilakukan dengan kategorisasi dan tabulasi. Untuk selanjutnya diberikan interpretasi terhadap data yang telah diolah tersebut.

\section{HASIL DAN PEMBAHASAN}

Sejarah Umum Perpustakaan Kelurahan Dusun Durup

Berdasarkan hasil wawancara dengan Lurah Dusun Curup diperoleh informasi bahwa Perpustakaan Kelurahan Dusun Curup merupakan perpustakaan yang berada di kelurahan, dimana koleksinya sebagian besar berasal dari Pemerintah Daerah Kabupaten Rejang Lebong dalam hal ini Dinas Perpustakaan dan Kearsipan Kabupaten Rejang Lebong. Pada awalnya koleksi-koleksi perpustakaan ini berada di Kantor Lurah Dusun Curup, selanjutnya karena pemerintah mengeluarkan program satu desa satu PAUD dan program Gernas Baku (gerakan nasional orang tua membaca buku) maka secara otomatis PAUD tersebut membutuhkan bahan bacaan atau buku untuk melaksanakan dan menyukseskan program tersebut. Untuk memperkuat dan mensupport program Gernas Baku (Gerakan Nasional orang tua membaca buku) maka Perpustakaan Kelurahan Dusun Curup yang awalnya berada di kantor lurah dipindahkan ke PAUD Restu Bunda yang dikelola oleh Ibu Sumiati, dimana tujuannya adalah untuk melaksanakan dan menyukseskan program pemerintah Gernas Baku tersebut.

Gernas Baku merupakan program pemerintah yang dicanangkan oleh pemerintah sejak tanggal 5 Mei 2018, yang bertujuan supaya orang tua anak gemar membacakan buku cerita kepada anaknya untuk menambah ilmu pengetahuan kepada anak-anaknya dan menumbuhkan minat baca anak-anak sejak dini. Program Gernas Baku ini dilaksanakan dua kali dalam satu bulan. Sehingga koleksi perpustakaan yang dimiliki kelurahan dapat dimnafaatkan dengan adanya program tersebut. Selain dimanfaatkan untuk program Gernas Baku, koleksi-koleksi tersebut juga dimanfaatkan oleh anak-anak di lingkungan Kelurahan Dusun Curup tepatnya RT. 01, untuk digunakan sebagai referensi dalam mengerjakan tugas sekolah.

Sampai saat ini Perpustakaan kelurahan Dusun Curup memiliki koleksi sebanyak 281 Judul (595 eksamplar). Jenis koleksi yang dimiliki perpustakaan Kelurahan Dusun Curup diantaranya koleksi buku anak-anak sekolah dasar, koleksi cerita rakyat, koleksi tokoh nasional, koleksi industri, koleksi pertanian, peternakan dan koleksi pendidikan.

\section{Pemberdayaan Perpustakaan Kelurahan dalam Kegiatan Belajar Mengajar di PAUD Restu Bunda Kelurahan Dusun Curup}

Pemberdayaan dan pemanfaatan perpustakaan kelurahan berangkat dari pemahaman bahwa perpustakaan merupakan pusat sumber belajar yang sekaligus sebagai wadah dari berbagai disipilin ilmu pengetahuan yang juga menunjang atau sebagai sarana dalam mencerdaskan kehidupan bangsa khususnya di bidang pendidikan dan pengajaran. Oleh karena itu, berdasarkan sejarah dari perpustakaan tersebut, dapat dipahami pemanfaatan perpustakaan ini dilatarbekangi karena adanya gerakan Gernas Baku dan program setiap satu desa satu PAUD. Menyikapi kedua program inilah maka pihak kelurahan mempunyai 
Pemberdayaan Perpustakaan Kelurahan dalam Menunjang Kegiatan Belajar Mengajar di Paud Restu Bunda Kelurahan Dusun Curup

Rhoni Rodin, Khusnul Khotimah, Lia Aprien

inisiatif untuk memanfaatkan koleksi perpustakaan bagi kegiatan beajar mengajar di PAU Restu Bunda.

Perpustakaan merupakan suatu unit kerja dari suatu badan atau lembaga tertentu yang mengelola bahan-bahan pustaka, baik berupa buku-buku maupun bukan berupa buku (non book material) yang diatur secara sistematis menurut aturan tertentu sehingga dapat digunakan sebagai sumber informasi oleh setiap pemakainya. Jadi, perpustakaan adalah suatu unit kerja dari suatu lembaga yang berisi koleksi buku sebagai penunjang dalam meningkatkan sumber belajar yang diatur untuk dibaca, dipelajari, dan dijadikan bahan rujukan.

Perpustakaan sebagai penunjang kegiatan belajar mengajar merupakan suatu keharusan dan amat penting dalam pendidikan. Suatu lembaga pendidikan tidak mungkin dapat terselenggara dengan baik jika para guru dan para siswa tidak didukung oleh sumber belajar yang diperlukan untuk penyelenggaraan kegiatan belajar mengajar. Smith dkk dalam buku ensiklopedianya yang berjudul "Educator's Encyclopedia" menyatakan "School Library is a Center for Learning", yang artinya perpustakaan itu merupakan sumber belajar (Eskha, 2018). Ditinjau secara umum, perpustakaan itu sebagai pusat belajar karena kegiatan yang paling tampak pada setiap kunjungan siswa adalah belajar, baik belajar masalah-masalah yang berhubungan langsung dengan mata pelajaran yang diberikan di kelas, maupun buku-buku lain yang tidak ada hubungannya dengan mata pelajaran. Akan tetapi apabila ditinjau dari sudut tujuan siswa mengunjungi perpustakaan, maka ada yang tujuannya untuk belajar, ada yang tujuannya untuk berlatih menelusuri buku-buku perpustakaan, ada yang tujuannya untuk memperoleh informasi, bahkan mungkin ada juga murid yang mengunjungi perpustakaan dengan tujuan hanya sekedar untuk mengisi waktu senggangnya atau sifatnya rekreatif.

Pendidikan anak usia dini merupakan kunci utama sukses tidaknya sebuah program pendidikan nasional suatu bangsa. Penelitian di bidang neurologi menyebutkan selama tahun-tahun pertama, otak bayi berkembang pesat dengan menghasilkan neuron yang banyaknya melebihi kebutuhan. Selanjutnya itu harus diperkuat melalui berbagai rangsangan karena sambungan yang tidak diperkuat dengan rangsangan akan mengalami atrohy (menyusut dan musnah), karena hal inilah yang mempengaruhi kecerdasan anak. Dosis rangsangan yang tepat dan seimbang akan mampu melipatgandakan kemampuan otak 5-10 kali kemampuan sebelumnya. Ironisnya, pemerintah kita terhitung terlambat dalam memberikan perhatian kepada anak usia dini. Mereka dibiarkan tumbuh dan berkembang dalam kondisi "ala kadarnya". Sampai saat ini diperkirakan 80 persen anak usia dini belum tersentuh PAUD. Tatkala anak usia dini di Singapura sudah terjangkau semuanya dengan PAUD, anak usia dini di Indonesia masih dibayang-bayangi oleh ancaman gizi buruk.

Layanan Perpustakaan Kelurahan Dusun Curup memiliki beberapa keunggulan dalam menunjang kegiatan belajar mengajar bagi siswa PAUD, yaitu:

Pertama, bersifat gratis. Bagi masyarakat yang tidak mampu menyekolahkan anaknya ke TK dapat memanfaatkan layanan ini. Perpustakaan Kelurahan yang berada di PAUD Restu Bunda ini bersifat gratis, sehingga siapa pun anggota masyarakat bisa memanfaatkannya.

Kedua, bersifat terbuka. Ruang layanan anak dapat diakses oleh siapapun tanpa membedakan status sosial, ekonomi, agama, suku, ras, dan golongan. Golongan menengah ke bawah yang selama ini terpinggirkan dapat memanfaatkan ruang layanan anak ini untuk memberi kesempatan kepada batita dan balitanya bermain sambil belajar serta berekreasi di perpustakaan. Hal ini terjadi di Perpustakaan Kelurahan Dusun Curup, dimana anak-anak yang memanfaatkan koleksi tidak hanya 
terbatas pada anak-anak usia dini saja, akan tetapi juga anak-anak tingkat Sekolah Dasar di Kelurahan Dusun Curup pun ikut memanfaatkan koleksinya untuk menambah ilmu pengetahuan.

Ketiga, menumbuhkan semangat membaca sejak dini. Dengan bermain di perpustakaan anak-anak sudah diperkenalkan sejak dini bahwa perpustakaan dengan segala aktivitas di dalamnya merupakan tempat yang menyenangkan. Dalam perkembangan selanjutnya diharapkan anak tidak menganggap membaca, menulis, dan berhitung sebagai pekerjaan yang membosankan melainkan menyenangkan.

Di sisi lain ada juga beberapa peranan perpustakaan Kelurahan Dusun Curup dalam menunjang kegiatan belajar mengajar di PAUD Restu Bunda antara lain:

1. Perpustakaan merupakan sumber ilmu pengetahuan dan pusat kegiatan belajar. Para siswa PAUD dapat menfaatkan koleksi yang ada untuk kegiatan belajar mengajar di PAUD.

2. Kumpulan bahan pustaka (koleksi) di perpustakaan memberikan kesempatan membaca bagi anak-anak PAUD yang mempunyai waktu dan kemampuan yang beraneka ragam.

3. Perpustakaan akan membantu anak-anak PAUD dalam meningkatkan dalam kemampuan membaca dan memperluas perbendaharaan kata dan bahasa.

4. Perpustakaan dapat menimbulkan cinta membaca, sehingga dapat mengarahkan selera dan apresiasi anak-anak PAUD dalam pemilihan bacaan.

5. Perpustakaan merupakan pusat rekreasi yang dapat memberikan hiburan yang sehat bagi anak-anak.

6. Kegairahan/minat baca anak-anak usia dini yang telah dikembangkan melalui perpustakaan sangat berpengaruh positif terhadap prestasi belajarnya.
7. Bahkan perpustakaan juga bagi anak-anak dapat menjauhkan diri dari tindakan kenakalan, yang bisa menimbulkan suasana kurang sehat dalam hubungan berteman diantara mereka.

\section{E. PENUTUP \\ Simpulan}

Pemberdayaan dan pemanfaatan perpustakaan dalam menunjang kegiatan belajar mengajar merupakan bentuk eksistensi dan aplikasi fungsi edukasi suatu perpustakaan. Perpustakaan mempunyai peran yang strategis bagi masyarakat kelurahan untuk meningkatkan pengetahuan dan pengalaman. Tujuan dibentuknya perpustakaan kelurahan adalah untuk sarana pelayanan kepada masyarakat sebagai penyedia sumber informasi yang cepat, tepat dan murah untuk menunjang program wajib belajar dan program pendidikan keterampilan masyarakat lainnya, serta membantu warga untuk mengembangkan kemampuan yang dimilikinya sehingga dapat bermanfaat bagi masyarakat di sekitarnya, sejauh kemampuan tersebut dapat dikembangkan dengan bantuan bahan pustaka. Fungsi ini disebut fungsi pendidikan berkesinambungan.

Perpustakaan Kelurahan Dusun Curup yang berada di PAUD Restu Bunda pada dasarnya sudah memberikan manfaat yang positif anak-anak PAUD. Anak-anak bisa memanfaatkan koleksi yang ada untuk kegiatan belajar mengajar. Akan tetapi dalam pengelolaannya, Perpustakaan Kelurahan Dusun Curup ini masih harus ditingkatkan terutama:

1. Penambahan koleksi. Koleksi yang ada harus ditingkatkan terutama berkaitan dengan koleksi untuk anak-anak tingkat PAUD.

2. Manajemen (pengelolaan) perpustakaannya. Suatu perpustakaan seharusnya dikelola secara professional sehingga bisa memberi manfaat secara optimal bagi pemustaka. 
3. Sumber Daya Manusia (SDM) yang menjadi tenaga pengelola perpustakaan ini belum ada, sehingga pengelolaannya terkesan apa adanya. Seharusnya suatu perpustakaan dikelola oleh SDM yang berlatarbelakang ilmu perpustakaan.

\section{DAFTAR PUSTAKA}

Darmono. (2015). Layanan perpustakaan desa untuk menumbuhkan kegemaran membaca masyarakat. Bimtek Tenaga Pengelola Perpustakaan.

Eskha, A. (2018). Peran Perpustakaan Sebagai Sumber Belajar. Jurnal Imam Bonjol, 2(1).

Gill, P. (2001). The Public Library Service: Ifla/Unesco Guidelines For Development. Ifla And Institution Publication.

Kementerian Pendidikan Nasional (Kemdiknas) Melalui Undang-Undang (Uu) Nomor 20 Tahun 2003 Tentang Sistem Pendidikan Nasional

Sutarno, N.S. (2008). Kamus Perpustakaan Dan Informasi. Jala.

Sutarno, N.S. (2006). Manajemen Perpustakaan: Suatu Pendekatan Praktik. Sage Publication.

Peraturan Menteri Dalam Negeri Nomor 30 Tahun 2006 Tentang Tata Cara Urusan Pemeritahan Kabupaten/Kota Kepada Desa

Surat Keputusan Menteri Dalam Negeri Dan Otonomi Daerah Nomor 3 Tahun 2001. Tentang Perpustakaan Desa / Kelurahan

Suwarno, W. (2011). Perpustakaan Dan Buku:Wacana Penulisan Dan Penerbitan. Ar-Ruzz Media.

Undang-Undang Nomor 43 Tahun 2007 Tentang Perpustakaan

Undang-Undang Dasar Negara Republik Indonesia 1945 